\title{
SURVEY OF CULTIVATED VEGETABLE CROPS IN RUPANDEHI DISTRICT, NEPAL
}

\author{
Chandra Bahadur Thapa \\ Butwal Multiple Campus, Butwal \\ cbthapa.2009@gmail.com
}

\begin{abstract}
Vegetable is very nutritious food and is considered to be protective food since it contains high amount of vitamins and minerals and also possesses medicinal value. In the present study, documentation of farmer's knowledge on cultivated vegetable crops was carried out in Rupandehi district during the year 2016. The objective of this paper is to identify, enumerate and to know the status of vegetable crops in this district. It was carried out by conducting semi-structured interview with the vegetable growing farmers, local people, members of Community Based Organizations with the help of standard questionnaire, checklist, Focus Group Discussion (FGD) and key informant interview. Altogether 50 plant species have been found to be cultivated in commercial scale as vegetable crops in Rupandehi district. Out of 50 plant spp.; 2 families, 4 genera and $5 \mathrm{spp}$. were monocots; and 9 families, 30 genera and $45 \mathrm{spp}$. were dicots. It is also found that fruit (55\%) is the widely used part of plant as vegetable. Other parts like leaf (21\%), inflorescence (4\%), root (8\%), tuber (2\%), corm $(6 \%)$, and bulb (4\%) are also used as vegetable. Most of the vegetable growing farmers (91\%) are economically benefited by the cultivation and selling of vegetable than other crops due to easily available seeds, fertilizers and pesticides in market; good facility of irrigation and accessible market in the study area.
\end{abstract}

Key words: Herbarium; off seasonal vegetable; Rupandehi, vegetable growing farmers, vegetable growing pocket area.

\section{INTRODUCTION}

Richness in genetic diversity of plants in Nepal is evident from the fact that more than 7000 species of flowering plants are estimated to be growing in the country and $79 \%$ of them have been collected, identified and preserved in the National Herbarium and Plant Laboratories, Godawari (NAA. 1995). Out of 7000 species, 400 comprise of food and horticultural crops, and of them, 200 species are in vegetable category (NAA. 1995). Vegetables are less risky, fast growing and best sources of income in comparison to other cereal crops. Due to the market access and increasing demand of vegetables, area for cultivation and productivity of vegetables is also increasing over the years. Commercialization of vegetable cultivation requires establishing markets and trading centers with adequate storage facilities close to farmer's production centers.

Nepal is an agricultural country where almost 65 percent people are involved directly and indirectly in agriculture (CBS, 2012). Agroecological variation in our country is high from Terai to high hills where many of the vegetables can be grown successfully. Production and productivity of the agricultural commodities in our country is still low as compared to other countries in spite of $65 \%$ people engaged in agriculture. According to the Central Bureau of Statistics (2009-10) and Ministry of Agriculture and Cooperatives (MoAC), vegetable crops are cultivated in only 7.3 percent of the total cultivable land in Nepal. 
The history of development of vegetables in Nepal dates back in early forties; however, its rapid development was started from 1972 when Vegetable Development Directorate (VDD) was established in the Department of Agriculture (Awasthi, 2003). Introduction and domestication of vegetables is an integral part of Nepalese agricultural systems. Both indigenous and exotic vegetables were cultivated in gardens of Ranas during the mid-19 $9^{\text {th }}$ century. At present, there are more than 247 cultivated vegetable crops throughout the world and more than fifty species of vegetables have already been domesticated in Nepal. Different forms of vegetables e.g. annual, biennial, perennial, herbs, shrubs, trees and climbers exist in Nepal. Due to wide range of climatic conditions ranging from tropical to alpine zone, it is possible to grow almost all types of vegetables in Nepal. Low hill farmers cultivate about $85 \%$ of the total local vegetables and mid hills farmers about $11 \%$. The cultivation of local vegetables is the lowest (32\%) in the high hills. High hill farmers mostly rely on wild vegetables (Buthathowki et al, 1993).

Different vegetables related organizations working in different parts of Nepal enhance the vegetables cultivation practices, collection and diversity maintenance of vegetables. Some of many indigenous vegetables have originated from Nepal. Intensive cultivation of vegetables is generally linked to availability of market. Due to the market facility in Terai different types of vegetables are being cultivated. Rupandehi is one of the Terai districts in Nepal where people cultivate different types of vegetable crops since ancient time. But no intensive research has been carried out to identify and enumerate the cultivated vegetable crops as well as to know the status of vegetable growing farmers in this district. So, this papers aims to identify the status of cultivated vegetable crops in Rupandehi district.

\section{MATERIALS AND METHODS}

\section{Study Area}

The study area Rupandehi District (latitudes: 27020'00" $\mathrm{N}$ to $28^{\circ} 47^{\prime} 25^{\prime \prime} \mathrm{N}$, longitudes: $83^{\circ} 12^{\prime} 16^{\prime \prime} \mathrm{E}$ to $83^{\circ} 38^{\prime} 16^{\prime} \mathrm{E}$ ), lies in Lumbini Zone, Western Development Region of Nepal. It borders India in South, and Palpa, Nawalparasi and Kapilvastu district in the North, East and West respectively. The altitude ranges from 100 $\mathrm{m}$ to $1229 \mathrm{~m}$ above sea level. The district covers an area of $1,360 \mathrm{sq}$. $\mathrm{km}$. The district is divided into fifty two village development committees (VDCs), five municipalities and one submetropolitan city. Geographically, it is divided into Chure region (14.5\%); Bhabar region $(0.6 \%)$ and Terai region $(84.9 \%)$.

It has lower tropical (below $300 \mathrm{~m}$ ), upper tropical (300- $1000 \mathrm{~m}$ ) and sub-tropical (1000$2000 \mathrm{~m}$ ) climate with maximum temperature about $43.7^{\circ} \mathrm{C}$ during summer (May- June) and about $8.75^{\circ} \mathrm{C}$ during winter (DecemberJanuary) and annual rainfall is about $1808 \mathrm{~mm}$. Pre-monsoon precipitation of $274.15 \mathrm{~mm}$ on an average is received in June and the maximum rainfall received for the observed period is $1034.5 \mathrm{~mm}$. Similarly, post monsoon month September is comparatively wet month that receives an average of $283.56 \mathrm{~mm}$ rainfall.

Rupandehi is agriculturally important south western district of Nepal. More than half of the land in the district ( 58.45 per cent or $82,622 \mathrm{ha}$ ) is under cultivation and 70 per cent $(98,956)$ of population are engaged in agriculture (Census, 2011). Major cereal crops produced in the district are paddy, wheat, corn, and finger millet; pulses are kidney bean, black gram, and soybean; and oilseed crops are mustard, sunflower, and peanuts. Among horticultural crops, the major fruits are mango, banana, litchi, jackfruit, and guava and the major vegetables are onion, 
potatoes, cabbage, cauliflower, tomatoes, radish, cucumber, ole, bottle gourds, and pumpkin. In addition to that, some spices and condiments are grown in the district such as turmeric, chili, and garlic.

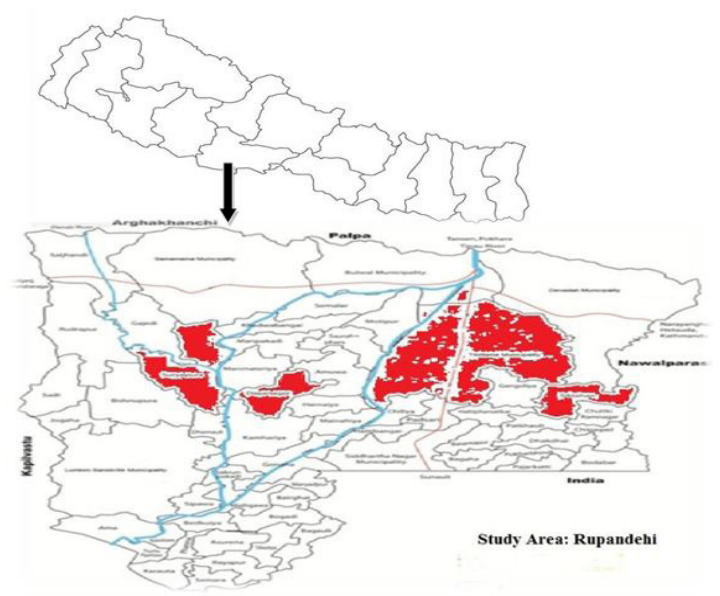

\section{Data Collection}

Both primary and secondary sources of information were used. The primary data were collected by extensive four time field survey of field visits of about one week each during the year 2016. Semi-structured questionnaires and checklist were applied for community survey. Personal interview, Focus Group Discussion (FGD) and key informant interview were also conducted with vegetable growing farmers, local people, elder people and the members of the Community Based Organizations (CBOs) to collect the different aspects of vegetable cultivation data in the study area.

\section{Plant Collection, Herbarium Preparation and Identification}

Most of the important vegetable species available in the study area were identified with the help of farmers and local people. Other unidentified plant specimens were collected for future reference. Collected plant samples were tagged, dried and mounted as voucher herbarium specimens following the standard technique
(Lawrence 1967). The unidentified specimens were later confirmed by consulting books and other standard taxonomic literatures (Hara et al. 1978, 1979, 1982; Polunin and Stainton 1984; Stainton 1988) and comparing with specimens deposited at Tribhuvan University Central Herbarium (TUCH) and National Herbarium (KATH). The prepared herbarium specimens were submitted to Department of Botany, Butwal Multiple Campus, Butwal.

\section{RESULT AND DISCUSSION}

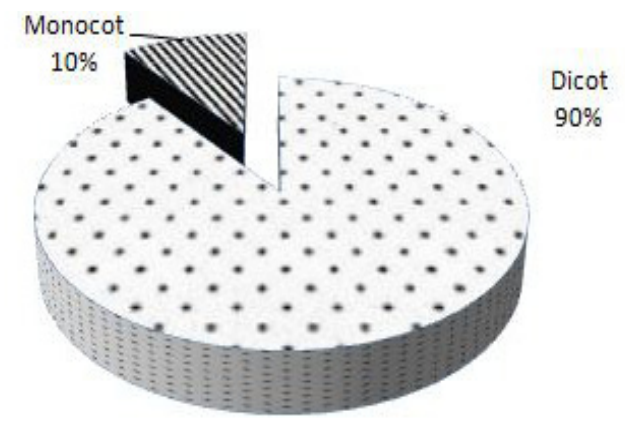

Fig1: Major Types of Taxa of Vegetable Crops

Altogether 50 plant species were found to be cultivated in commercial scale as vegetable crops in Rupandehi district. Out of 50 plant spp.; 2 families, 4 genera and $5 \mathrm{spp}$. were monocots; and 9 families, 30 genera and $45 \mathrm{spp}$. were dicots (Table: 1 ). Among them $90 \%$ species were dicots and $10 \%$ species were monocots. Some of the monocot spp. are Allium cepa L.(Onion), Allium sativum L.(Garlic), Alocasia macrorrhizos (L.)G. Don (Giant Taro), Amorphophallus paeonifolius (Demst) Nicolson (Elephant Foot Yam), and Colocasia antiquorum Schott. Var. esculenta L.(Yam). Major dicot vegetable crops are Abelmoschus esculentus (L.) Moench (Lady's finger), Brassica oleraceae var. botrytis L. (Cauliflower), Brassica oleraceae var. capitata L. (Cabbage), Brassica oleraceae var. italica L. (Broccoli), Brassica rapa L. (Turnip), Cucumis sativus L. (Cucumber), Cucurbita 
Survey of Cultivated Vegetable...

maxima D. Don. (Pumpkin), Lagenaria siceraria (Molina) Standl. (Bottle gourd), Daucas carrota L. var. sativa DC. (Carrot), Luffa cylindrica (L.) Roem. (Sponge gourd), Lycopersicum esculentum Mill (Tomato), Solanum tuberosum L. (Potato), Raphanus sativa L. (Radish), Vigna sinensis (L.) Savi ex Hassk (Cow pea), Solanum melongena L. (Brinjal) etc.

Table: 1 Name of Vegetable Crops Cultivated in Study Area.

\begin{tabular}{|c|c|c|c|c|}
\hline Scientific Name & English Name & Local Name & Family & Parts Used \\
\hline Abelmoschus esculentus (L.) Moench & Lady's finger/Okra & Bhindi & Malvaceae & Fruit \\
\hline Allium cepa $\mathrm{L}$. & Onion & Pyaj & Amaryllidaceae & Bulb/Leaf \\
\hline Allium sativum $\mathrm{L}$. & Garlic & Lasun & Amaryllidaceae & Bulb/Leaf \\
\hline Alocasia macrorrhizos (L.) G. Don & Giant Taro & Thulo Pindalu & Araceae & Corm \\
\hline Amaranthus caudatus L. & Love-lies-bleeding & Latteko Sag & Amaranthaceae & Leaf \\
\hline $\begin{array}{l}\text { Amorphophallus paeonifolius (Demst) } \\
\text { Nicolson }\end{array}$ & Elephant Foot Yam & Oal & Araceae & Corm \\
\hline Anthum sowa Roxb. & Indian Dil & Sounp Sag & Umbelliferae & Leaf \\
\hline Benincasa hispida (Thunb.) Cogn & Wax Gourd & Kuvindo & Cucurbitaceae & Fruit \\
\hline Beta vulgaris L. & Beetroot & $\begin{array}{l}\text { Gulio Mula/ } \\
\text { Chukandar }\end{array}$ & Amaranthaceae & Root \\
\hline Brassica campestris L. & Indian Rape & Toriko Sag & Brassicaceae & Leaf \\
\hline Brassica junceae var. folicosa Bail. & Broadleaf Mustard & Rayo Sag & Brassicaceae & Leaf \\
\hline Brassica oleraceae var. botrytis L. & Cauliflower & Phulgobi & Brassicaceae & Inflorescence \\
\hline Brassica oleraceae var. capitata L. & Cabbage & Bandagobi & Brassicaceae & Leaves \\
\hline Brassica oleraceae var. italica $\mathrm{L}$. & Broccoli & Brocauli & Brassicaceae & Inflorescence \\
\hline Brassica rapa $\mathrm{L}$. & Turnip & Salgam & Brassicaceae & Root \\
\hline Canavalia ensiformis (L.) DC. & Sword bean & Tarbare/Tate simi & Fabaceae & Fruit \\
\hline $\begin{array}{l}\text { Capsicum frutscence L. var. } \\
\text { cerasiforme L.H. Bailey }\end{array}$ & Cherry Pepper & Jyanmara Khursani & Solanaceae & Fruit \\
\hline $\begin{array}{l}\text { Capsicum frutscence L. var. conoides } \\
\text { L. H. Bailey }\end{array}$ & Cone Pepper & Dallay Khursani & Solanaceae & Fruit \\
\hline $\begin{array}{l}\text { Capsicum frutscence L. var. grossum } \\
\text { L.H. Bailey }\end{array}$ & Bullnose Chilly & Bhende Khursani & Solanaceae & Fruit \\
\hline $\begin{array}{l}\text { Capsicum frutscence L. var. longum } \\
\text { L.H. Bailey }\end{array}$ & Long Pepper & Jire Khursani & Solanaceae & Fruit \\
\hline Chenopodium album L. & Goosefoots & Betheko Sag & Chenopodiaceae & $\begin{array}{l}\text { Leaf/Young } \\
\text { shoot }\end{array}$ \\
\hline Coccinia grandis(L.) Voigt & Ivy Gourd & Kunru & Cucurbitaceae & Fruit \\
\hline Coriandrum sativum L. & Coriander & Dhaniya & Umbellifereae & Leaf \\
\hline $\begin{array}{l}\text { Colocasia antiquorum Schott. Var. } \\
\text { esculenta L. }\end{array}$ & Yam & Pindalu & Araceae & Corm/Leaf \\
\hline Cucumis sativus L. & Cucumber & Kankro & Cucurbitaceae & Fruit \\
\hline Cucurbita maxima D. Don. & Pumpkin & Pharsi & Cucurbitaceae & Fruit/Leaf shoot \\
\hline Daucas carrota L. var. sativa DC. & Carrot & Gajar & Umbelliferae & Root \\
\hline
\end{tabular}


Lagenaria siceraria (Molina) Standl.

Lepidium sativum $\mathrm{L}$.

Luffa acutangula (L.) Roxb.

Luffa cylindrica (L.) Roem.

Lycopersicum esculentum Mill

Momordica balsamina L.

Momordica charantia L.

Momordica dioica Roxb.

Moringa oleifera Lam.

Phaseolus lunatus L.

Phaseolus vulgaris L.

Pisum sativum L.

Raphanus sativa $\mathrm{L}$.

Sachium edule (Jacq.) Sw.

Solanum melongena $\mathrm{L}$.

Solanum tuberosum L.

Spinacea olaracea var. inerrus L.

Trichosanthes anguina $\mathrm{L}$.

Trichosanthes dioica Roxb.

Trigonella foenumgraceum $\mathrm{L}$.

Vicia feba $\mathrm{L}$.

Vigna sinensis (L.) Savi ex Hassk

Vigna unguiculata var. Sesquipedalis
Bottle Gourd

Peper Cres

Ridge Gourd

Sponge Gourd

Tomato

Balsam apple

Bitter Gourd

Spiny Gourd/Teasle Gourd

Drumsticks

Lima

Bean/

Butterbean

Garden Pea

Radish

Chayote

Brinjal/Egg plant

Potato

Round Seeded Spinach

Snake Gourd

Pointed Gourd

Fenugreek

Broad Bean

Cow Pea

Yard-long Bean
Common Bean

Louka

Chamsur Sag

Pate Ghiraula

Ghiraula

Golbheda

Barela

Titekarela

Jangali Karela/Kheksi

Sahijan

Hiude Simi

Asare Simi/Lauri

Simi

(L.) Verdc

There are fifteen pocket areas for the commercial production of vegetables in Rupandehi districts viz. Dhakdhakai, Parroha, Gajedi, Khudabagar, Dhamauli, Suryapura, Harnaiya, Kamhariya, Rayapur, Jogada, Majhagawan, West Amuwa, Siktahan, Siddharthanagar municipality and Devdaha municipality (DADO, 2072).

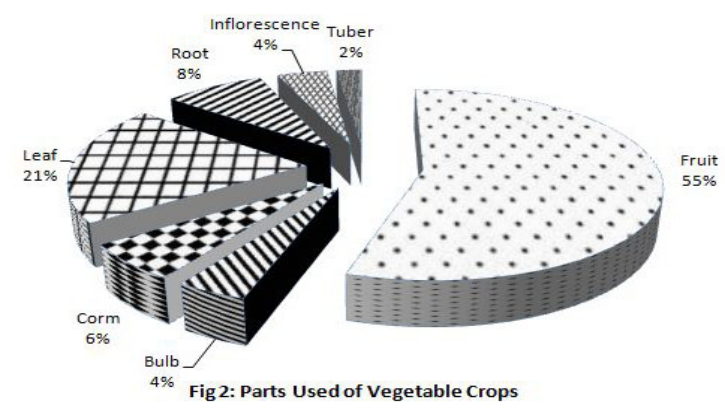

The present research has found that fruit (55\%) is widely used part of plant as vegetable. Other parts like leaf (21\%), inflorescence (4\%), root $(8 \%)$, tuber $(2 \%)$, corm $(6 \%)$, and bulb (4\%) are also used as vegetable. Fruit is large and most 
nutritive as well as delicious part of plant so people consume it as vegetable.

Underground parts like tuber of Solanum tuberosum, corm of Colocasia antiquorum Var. esculenta, and bulb of Allium cepa are most widely used as vegetable in study area.

Farmers cultivate vegetables in both summer (rainy) and winter seasons. The summer season vegetables are Lagenaria siceraria (Molina) Standl. (Bottle gourd), Vigna sinensis (L.) Savi ex Hassk (Cow pea), Momordica charantia L. (Bitter gourd), Solanum melongena L. (Brinjal), Solanum melongena L. (Sponge gourd), Luffa acutangula (L.) Roxb. (Ridge gourd), Trichosanthes anguina L. (Snake gourd), Trichosanthes dioica Roxb. (Pointed gourd), Cucurbita maxima D. Don. (Pumpkin), Abelmoschus esculentus (L.) Moench (Lady's finger), Benincasa hispida (Thunb.) Cogn (Wax gourd), Coccinia grandis(L.) Voigt (Ivy gourd), Momordica dioica Roxb. (Spiny gourd), Cucumis sativus L. (Cucumber) etc. Similarly the winter season vegetables are Brassica oleraceae var. botrytis L. (Cauliflower), Brassica oleraceae var. capitata L. (Cabbage), Brassica oleraceae var. italica L. (Broccoli), Lycopersicum esculentum Mill (Tomato), Solanum tuberosum L. (Potato), Daucas carrota L. var. sativa DC. (Carrot), Raphanus sativa L. (Radish), Allium cepa L. (Onion), Allium sativum L. (Garlic), Pisum sativum L. (Pea) etc.

The vegetable growing farmers cultivate different types of seasonal as well as off seasonal vegetable crops in their farm by using different types of pesticides in the study area. The amount of off seasonal vegetables they cultivate is very less as compared to seasonal vegetable crops due to difficult in pest control and field management. Off- season vegetable production is defined as the production of vegetable after or before their normal season of production. Off seasonal vegetable crops are more susceptible to pest than seasonal crops, so they use more pesticides in high dose frequently in these vegetables. Government of Nepal has launched the Commercial Offseason Vegetable Production Pocket Program in 17 hilly districts during the fiscal year 2070/71. In Nepal, the amount of vegetable production was $13,419 \mathrm{~kg}$ per hectare during 2013/14 and 13,412 kg per hectare in 2014/15 (MoAD, 2015). The total amount of cultivated area for vegetable in Terai was $1,70,736$ hectare and the total production was 70,681 $\mathrm{kg}$ per hectare (VDD, 2015). Similarly the total cultivated area for vegetable in Rupandehi was 4,716.5 hactares and the total production during 2071-072 was 1,19,213.1 metric tons (DADO, 2072). Fifteen vegetable growing pocket areas are selected in Rupandehi district to produce vegetable crops in commercial scale. DADO, Rupandehi has launched 'Youth Centered Commercial Vegetable Production Program' to involve the youth (18-50 years age group) for the production and export of vegetable. Sixty youth farmers were selected to conduct this program during 2071-2072 (DADO, 2072). For this program youth farmers receive some grant from DADO, Rupandehi and cultivate vegetable in commercial scale. They produce vegetable to sale in Nepali market but some of them export to India to some extent. Few amount of vegetable is also imported to Rupandehi district through Belhiya (Sunauli) boarder. Nepal imports different types of vegetable from India which amounts to 64,441 metric tons and cost NRs 17,75,224 through Belhiya (DADO, 2072).

Most of the vegetable growing farmers (91\%) are economically benefitted by the cultivation and selling of vegetable than other crops due to easily available seeds, fertilizers and pesticides in market; good facility of irrigation and accessible 
market in the study area. It has become the main source of income to support the livelihood for them. Vegetable crops are efficient to generate cash even from a small plot of land in a short period of time and helps farmers reduce poverty. The value of vegetable production equals or even surpasses the value of cereal production (Gurung et.al 2016). There are many small markets (Hatbazaar) in study area. They also sell vegetables in big markets like Manigram, Valbari, Kotihawa, Jogikuti, Patkhauli bazaar, Birta bazaar, Bhairahawa, Butwal etc. They also export vegetables to India due the presence of nearby border. They sell vegetable themselves in market or sell to vegetable broker. Most of them sell vegetable to the broker to save their time in the market. There are some collection centers for vegetable in the study area but most of them transport vegetable personally. Some of the farmers collectively do the reservation of jeep/van to transport the vegetable. It has been found that vegetable growing farmers cultivate vegetable in 5 katha to 2 Bigha land in the study area. Most of the farmers cultivate vegetable in traditional way since a long time. They are illiterate and ignorant and did not know about modern technique of vegetable cultivation and pesticide use. Sometimes District Agricultural development Office (DADO) and some NGOs conduct training program to cultivate vegetable in modern technique, method of proper use and safe handling of pesticides, preparation and use of botanical pesticides etc. Such training is given to only limited number of farmers. DADO, Rupandehi has launched 'Youth Centered Commercial Vegetable Production Program' for the farmers of age group 18 to 50 years. This program provides some grant for commercial production of vegetable.

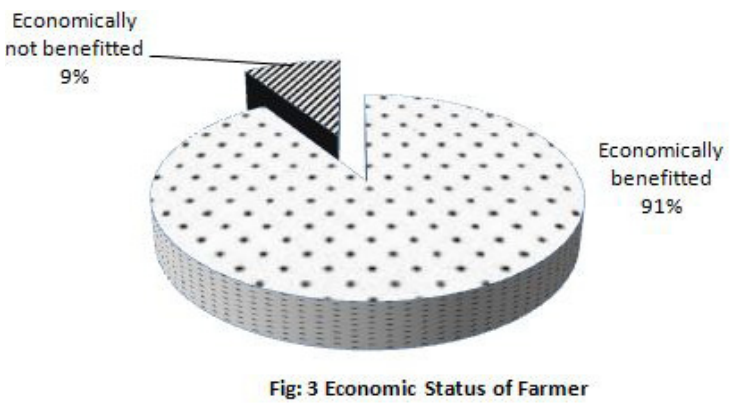

Some farmers $(9 \%)$ did not get benefit by the cultivation of vegetable crops in the study area. In some places, there is a lack of irrigation and transportation facility. Nilgai also causes a heavy loss of vegetable in few wards of Dayanagar and Suryapura VDC, which are adjoining to Lumbini conservation area. They also got loss due to high incidence of pest, ineffectiveness of pesticide and high production rate but minimum selling rate and low price rate of vegetable in the market. Sometimes vegetable gets rotten at the farm due to the lack of storage facility, transportation facility and low selling rate in the study area.

\section{CONCLUSIONS}

The study area is rich in indigenous and exotic vegetable crops. Local people cultivate different types of summer, winter and off seasonal vegetable crops in their field but in commercial scale they cultivate 50 plant species as vegetable crops. Dicots are widely used as vegetable crops than monocots. The amount of off seasonal vegetables they cultivate is very less as compared to seasonal vegetable crops due to difficult in pest control and field management. Most of the vegetable growing farmers are benefited by the cultivation of vegetable crops than other crops due to the availability of facilities like seeds, fertilizers, pesticides, transportation, market, irrigation etc. in the study area. To increase the participation of local people for the cultivation of vegetable crops, concerned Government 
agencies should manage the transportation of vegetable from farm to the market and the number of vegetable collection centers should be increased and well organized. Illegal import of vegetable from India should also be banned to encourage farmers in the study area. Nilgai, present in Lumbini Conservation area, should be controlled by concerned authorities otherwise they should provide compensation of loss caused by them in the study area, especially in Dayanagar and Suryapura VDCs.

\section{ACKNOWLEDGEMENT}

I would like to thank Dean Office, Institute of Science and Technology, Tribhuvan University, for providing financial support. Similartly, I am thankful to Mr. Ram Bdr Khatri, Plant Protection Officer, DADO, Rupandehi for providing valuable suggestion and information and to all farmers for their assistance in the field to collect valuable data. I am also thankful to Dr. Anant Gopal Singh for his help to identify plant species.

\section{REFERENCES}

Awasthi, B.D. (2003). Vegetable production and marketing in Kathmandu valley. Community Rural Development Society, Devinagar, Kathmandu.

Budathoki, K., G.B. Gurung, and D.P. Lohar (1993). Vegetable Crops: Indigenous Knowledge and Technology in the Western Hills of Nepal. In Indigenous Management of Natural Resources in Nepal (Eds D. Tamang, G.J. Gill, and G.B. Thapa) HMG/N W1NROCK International.

CBS, (2064). District Profile of Rupandehi, Branch of Stastistic Office, Kapilvastu (Kapilvastu, Rupandehi, Arghakhanchi), Nepal Government.

CBS, (2011). Population Census National Report 2011. HMG/National Planning Commission Secretariat, Kathmandu.

DADO, (2072). Annual Agricultural Development Program and Statistical Book, 2071-2072. District Agricultural Development Office (DADO), Rupandehi, MoAD, Nepal.
Gurung, B., RB Thapa, DM Gautam, KB Karki, and PP. Regmi (2016). Commercial vegetable farming: an approach for poverty reduction in Nepal. Agronomy Journal of Nepal (Agron JN), Vol.4, 2016, Institute of Agriculture and Animal science, Rampur, Chitwan.

Hara, H., A.O. Charter and L.H.J. Williams (1982). An Enumeration of Flowering Plants of Nepal. Volume III. Trustees of British Museum (Natural History), London.

Hara, H. and L.H.J. Williams (1979). An Enumeration of the Flowering Plants of Nepal. Volume II. Trustees of British Museum (Natural History), London.

Hara, H., W.T. Stearn and L.H.J. Williams (1978). An Enumeration of the Flowering Plants of Nepal. Volume I. Trustees of British Museum (Natural History), London.

Lawrence, G.H.M. (1967). Taxonomy of Vascular Plants. Oxford and IBH Publishing Co. Ltd. New Delhi, India.

MoAD, (2015). Statistical Information on Nepalese Agriculture, Government of Nepal, Ministry of Agricultural Development, Agri-Business Promotion and statistics Division, Statistics Sector, Singha Durbar, Kathmandu, Nepal

NAA (1995). Plant Genetic Resources Profile Study. Nepal Agricultural Association, Kathmandu, Nepal.

Polunin, O. and A. Stainton (1984). Flowers of the Himalayas. Oxford Press, New Delhi, India.

Stainton, A. (1988). Flowers of the Himalayas: A Supplement. Oxford University Press, Bombay, Calcutta, Madras.

The Plant List, (2013). The Plant List, A working list of all plant species, http://www.theplantlist.org.

VDD, (2015). National Statistics on Vegetable, Potato and Spices, 2014/15. Ministry of Agriculture and Development (MoAD), Nepal.

(Received 11 Oct 2017, revised accepted 2 Dec 2017) 